\title{
Effect of bioagents and fungicide against earlyblight disease of tomato (Lycopersicon esculentum L.)
}

QAYSSAR NADHIM ZGHAIR*1, ABHILASHAA. LAL, MUSADAQ MNSOOR MANE AND SOBITA SIMON

${ }^{1}$ Department of Plant Pathology, Allahabad School of Agriculture, Sam Higginbottom Institute of Agriculture, Technology and Sciences, ALLAHABAD (U.P.) INDIA

\section{ARITCLE INFO}

$\begin{array}{ll}\text { Received } & : 28.03 .2014 \\ \text { Revised } & : 26.07 .2014 \\ \text { Accepted } & : 12.08 .2014\end{array}$

\section{KEY WORDS :}

Alternaria solani, fungicides, Management, Pseudomonas

fluorescens, Trichoderma harzianum, Tomato

*Corresponding author:

\begin{abstract}
An experiment was conducted to evaluate the effect of bio agents (Trichoderma harzianum and Pseudomonas fluorescens) and fungicides (mancozeb) against earlyblight of tomato caused by Alternaria solani (Ell. and Mart.) at the experimental field of Department of Plant Protection, Sam Higginbottom Institute of Agriculture, Technology and Sciences, Allahabad during Rabi Season (2013-2014). Seven treatments including control with three replications were taken up using RBD. The treatments comprised of seed treatment and foliar spray (once and twice) of bio-agents Trichoderma harzianum and Pseudomonas fluorescens while fungicide taken up was mancozeband Control (spray of plain water) was applied. Observation for percent disease intensity was recorded at 70, 90 and 105 days after transplanting. Minimum disease intensity was recorded in mancozeb with twofoliar spray $(15.43 \%, 17.90 \%$ and $20.47 \%$, respectively) as compared to control which recorded maximum disease intensity $(25.50 \%$, $33.47 \%$, and $48.73 \%$, respectively). The bio agents Trichoderma harzianum and Pseudomonas fluorescens (seed treatment + two foliar spray) were also effective in reducing the disease intensity.
\end{abstract}

How to view point the article : Zghair, Qayssar Nadhim, Lal, Abhilasha, A., Mane, Musadaq Mnsoor and Simon, Sobita (2014). Effect of bioagents and fungicide against earlyblight disease of tomato (Lycopersicon esculentum L.). Internat. J. Plant Protec., 7(2) : 330-333. 